\title{
Functional Basis of Anyigba, Nigeria as a Fast-Growing University Town
}

\author{
Abike Ibidunni Awosusi \\ Centre for the Built Environmental Studies, Ado-Ekiti, Ekiti State, Nigeria \\ Olusegun Oriye \\ Department of Architecture, College of Environmental Sciences, \\ Joseph Ayo Babalola University, Ikeji-Arakeji, Osun State, Nigeria \\ Email: segunoriye@gmail.com, arcooriye@yahoo.co.uk
}

\author{
Doi:10.5901/mjss.2015.v6n4s2p182
}

\begin{abstract}
This study is carried out to study the functions of Anyigba town especially its commercial functions. It was done to study the adequacy of the commercial functions which the town performs to the inhabitants of the town and the surrounding towns in the region. The establishment of the University coupled with improved economy has encouraged migration as people have moved to the town temporarily or permanently to benefit of its functions. As these people have come to the town, there is a need for their commercial needs to be met. The problem of the adequacy of the commercial functions of Anyigba town includes the lack of numerous markets, distance from far places to the market and the lack of organization in the manner of arrangement. It is therefore suggested that there should be a new plan for the restructuring of the existing market, market men and women encouraged to take loans to purchase goods of high quality and that corner shops and shopping arcades should be built in major areas of the town.
\end{abstract}

Keywords: Functional, Commercial, Town, Urban Activities, New Plan

\section{Introduction}

The functional variations in urban activities have led to many systems of classifying towns. This is generally determined by a town's employment structure or sometimes by the value of its activities; classification depends on a town's specialized activity. This is of great importance to geographers and especially the planners. Measures of functional specialization are essential and are also useful devices for describing level of urbanism. Functional significance of places, whether rural or urban, varies. While some urban areas take off from mining, some are industries centers, some also specialize in wholesale and retail trade, and others too have interest in transportation and service rendering businesses.

At the small city level, some peripheral industrial towns based on Agricultural, mineral and forest resources appear. Also, some scattered towns specialize in administration or education usually containing state capital or colleges especially in western Nigeria. The variation in function of places on the long run affects the type of land use. It is therefore responsible for the variation a land use. More important than its functional class is the role a Town performs in the regional and national economy. This is revealed largely by the pattern and the strength of its external relationship to the surrounding towns and the nations.

The functions which an area performs, encourages and or discourages migration. People tend to migrate rewards such areas because of the functions they perform and their overwhelming attractions. This therefore increases the population of such areas; as the population increases, so also the demand for land in the area; thereby leading to inadequacy of land for development in the city. Many of these areas of growth are focal points for development such as industries, education, employment and housing. The centrifugal force tends to be a scourge that results in over-crowding though this is an indication that both the pull and push factors manifests in cities.

'Migration calls' on the rural-urban movement has not abated the cities, as migrants still swarm the cities mostly because of the functions such places perform. The urban population of the developing countries has grown faster than the developed regions hence, the share in urban population has been rising since the 1950's when the patterns of urban growth in the two regions (the less developed and the developed) has shown divergence. 


\section{Study Area}

The Study Areas is Anyigba in Eastern Part of Kogi State in Dekina Local Government Area.

Anyigba lies between longitude $7^{0} 12^{1}$ East of the Greenwich Meridian and latitude $7^{0} 36^{1}$ North of the Equator. It is on the south eastern direction of Lokoja (capital of Kogi State) and the bearing of Anyigba from Lokoja is $135^{\circ}$.

Like most parts of Kogi State, the climate of Anyigba lies within tropical hinterland. The climate region is characterized partly by double and single maximum rainfall patter with about four months of dry season. In the mornings, Relative Humidity generally rises to over $80 \%$ and falls between $50 \%-70 \%$ in the Afternoon during the wet season. Rainy season occur between April through October and the peak is September. Rainfall in Anyigba is seasonal which means, it is not all the year round. Extreme variations in total Rainfall for July and August are also general characteristics of rainfall here. Heavy rains of conventional type falls here and this sometimes amount up to about $978.5 \mathrm{~mm}$, but may be more. The mean rain days for this area are approximately 73.90days.

In general, the rate of rainfall deceases inland from the southern part of the region. This area comes under the trade wind for part of the year. Temperature is therefore very high. The mean monthly temperature ranges between $21^{\circ} \mathrm{C}$ and $32^{\circ} \mathrm{C}$. The daily range in temperature is about $6^{\circ} \mathrm{C}$ and the annual variation is about $3^{\circ} \mathrm{C}$ in some years (CRIN, 1987). The highest temperature occurs just before the rainy season begins.

Anyigba falls into the lowland area and specifically, it is the lowland and scarpland of the south eastern Nigeria. It lies at the western part of Enugu where the two Plateaus are separated by Anambra and Udi River Line. The area is on the south-western dipping area of the cretaceous sandstone which stretches in the south-western direction. The relief is also cornposed of rounded to flat top hills that was seen as femiginised sandstone. The upper and lower coal measures are subjected to gully erosion. Anyigba is laid out on a gently undulating land between 270 and 390 metres above see.

Anyigba area is located within the southern guinea savanna zone. Although species common to the northern guinea savanna also occur here but is not as much as that of the northern guinea savannah mostly because of man's impact. The distribution of tress, gross etc., is determined by factors such as; fire, Demographic pressure, patterns of cultivation, clearing and relief. Trees found here do adopt to dry conditions (deciduous) and they shed their leaves in the dry season to control evapotranspiration. These trees are however small and widely spaced with thick thin leaves and rough banks because conditions are not as favourable as those found in the southern zone of Nigeria such trees are: Malima, Oil bean tree, Mango, Locust bean tree, Cashew trees, Shea butter tree and Isoberlina. It is clear that much of the study area has reasonably thick vegetation especially during the rainy season. However, in areas with little grass undergrowth, the soil is exposed to leaf falls and occasionally rain drops impact facilitates the breakup of soil surface as subsequent transportation through runoff.

\subsection{Occupation}

The major occupation of inhabitants of Anyigba town is farming. Most of the farmers practice subsistence farming. They produce crops for their immediate family needs and they sell crops when in excess. They use local tools for their farming practice.

\subsection{Geology}

Anyigba region is part of the Idah/Ankpa Plateau. The land form of the area undulates gently, and is covered by soil with little exposed bedrock. Immediately to the North of Anyigba, a hill rises to over 50 metres above sea level and has a slope 20 percent. The region generally does not contain well developed valley formation although there is a valley to the North of the town. However, it is likely that the underlying sandstone formations contain aquifers which could be tapped for water by drilling (Anyigba Master Plan 1974-2005).

\subsection{Land Use}

Anyigba in $2001 / 2002$ occupied an estimated total land area of $11.07506 \mathrm{qkm}$ as compared to about $2.25 \mathrm{sqkm}$ in 1974 (T.P.D.B., 2002). A major part of the Area (62.28\%) is devoted to residential land use (inclusive of residential in prominence in the university). This is followed in prominence by services accounting for as high as $23.27 \%$, the bulk of which is taken by educational land use as either promoted by missionary activities in the town or enhanced by the establishment of the university. Other uses worthy of note are cultivation/green area (jointly accounting for $7.94 \%$ ) and transportation (3.64\%). 
The bulk of the conservation area is in form of an erstwhile foreign Assisted forestry project (of teak mainly) now part of the university as well some cemeteries. The 3.64\% fraction taken by transportation is partly virtue of the town's location as a junction town for the Dekina, Idah, Ankpa regional roads from which other lower order roads radiate in hierarchy.

The estimated 21.1 hectares (or 1.91\%) agricultural land use can be deceptive as it refers to identified land put to cultivation or orchard aside from oil palm which grows freely in most open land and has taken a major attention of farmers in addition to their agricultural land. (UNDP paper on urban and housing indicators study: Kogi State Segment (2002).

\subsection{Population}

The 2002 household survey estimates by the United Nations Development programme (UNDP), Kogi State segment put the 2001 population of the core area of Anyigba at about 18,907 or (46.38\%) of that of the total metropolitan area which was $40.765 \%$. Of this (urban core area) population, an estimated 9,425 (or 49.85\%) were males while 9,482 (or 50.15\%) were females. On the other hand, $49.93 \%$ of the population of the entire metropolitan area of Anyigba (i.e. 20,354$)$ was males as against $50.07 \%$ or 20,411 females. This latter figure was in line with the sex ratio from the 1991 population census figures.

The slightly lower sex ratio in the core area is not surprising, given the fairly high Muslim population in this indigenous area and the associated polygamous family set up as compared to the newer areas where missionary influence may have induced a high proportion of Christians. Although the exclusive sex ratio figure for the non-core area was not the concern, this relative fraction may have been responsible for the increased sex ratio for the entire town as compared to the core (UNDP, 2002).

Dependency ratio seems to be lower in Anyigba than in most other parts of Kogi State generally and Dekina local government area specifically. There is a small but remarkably higher figure for male above 60 years (955 or 4.6\%) than the female (840 or 4.2\%). Given the higher risk to which men are prone, this is indicative of the greater search for greener pastures by men than women in such urban centres and that some of the men stay put there if aspirations are not met or even after retirement (UND, 2002).

\subsection{Residential Density}

With a population of about 18,908 and an estimated residential area of 99.2 hectares, the core area of Anyigba has a residential density of 191 persons per hectare as against $59.11 \%$ (residential density) for the entire metropolitan area. The residential density for the core area which formed the bulk of the area of Anyigba in 1974 was estimated at 125 persons per hectare (Dar-Alhandasah-shair and partners, 1976 p.2132). These figures indicate that while Anyigba as a whole continued to witness a physical expansion and steady increase in population, the core has not quite expanded to receive its segment. Here, but for few narrow roads, the facilities and services are more easily accessed and cheaper modes of transportation, hence the lure.

The spread of space consuming socio-economic facilities such as educational, health institutions, petrol stations etc., to the outlying areas of the town where land is far cheaper has also forced the population to spread along especially following existing access roads and points of traffic interchange. This leaves pieces of indigenous lands in-between such outlying residence, hence the low overall residential density (UNDP, 2002). The situation is further favoured by the expansive compounds common in the town with detached toilets and spacious courtyards.

\subsection{Annual Population Growth Rate}

\subsubsection{Population Growth Rate}

The national population commission project medium-Variant growth rate for Kogi State as (3.61\% and 3.63\%) for the three five years-interval period of 1991-1995, 1996-2000 and 2001-2005 are most appropriate for Anyigba Town. This is especially so as Dar-Alhandasah (Shair and partners) consultant Town panners, 1976, had estimated between $3.4 \%$ and $3.2 \%$ for the two 10 years interval periods covering the same stretch of time even while not envisaging that the town will take on an additional focal socio-cultural status among the Igalas and become a university town before the expiry periods. 


\subsubsection{Net Migration}

There are no reliable data on vital statistics for Anyigba Town. For instance, deaths were not recorded for the year 2001 while birth records were not available for some months. Going by the vital statistics figures for Lokoja, it is assumed that Anyigba must have been witnessing about the same rate of net migration as Lokoja, the population size factor being relevant for actual population (UNDP, 2002). Considering the indication by respondents (2002, Housing Survey). The rate of natural increase is bound to be high. The survey indicated that respondents have adequate access (100\%) to primary health facilities and the impact of the university which had a record of over 1,500 population as at 2002 and has now risen to about 10,000 population in year 2004 .

This research work will study the functions of Anyigba especially its commercial functions which it performs for the dwellers and its commercial relationship with its surrounding villages like Egume, Odu, Agbeji, lyale to mention but a few. Also, this study will give certain recommendations of how the commercial functions of Anyigba can be boosted and then give a proposition on the commercial land use which includes development of ownerships within certain areas, shopping complexes on some major stretches and lastly give a proposal on the re-organization of the central market. This, a belief will solve some, if not all aspects of the problems faced in the commercial aspect of the functions of Anyigba.

\section{Statement of the Problem}

Some of the problems militating against the commercial functions of Anyigba included the following:

(i) The lack of numerous markets to adequately meet the commercial needs of the people.

(ii) The lack of organization in the manner of arrangement of goals for sales like cloths, raw food stuffs, spare parts, shoes etc., in the existing market in yet another problem.

\section{Objective of the Study}

The main aim and/or focus of this research work is to study the functional Bases (i.e. Importance of) of Anyigba as a commercial Town. The objectives through which the aims can be achieved are as follows:

(i) To study the scope of the commercial nature of Anyigba and the commercial land use of the town. (Examine the adequacy of existing commercial infrastructures).

(ii) To recommend ways of improving the commercial infrastructure on the ground.

(iii) To examine the historical Basis of the commercial nature of Anyigba.

\section{Methodology}

This can be regarded as the method of collecting data. There are two main sources of data collection and they are the primary source and the secondary source. These sources shall also be used in this work.

(a) The primary source: This will include the use of questionnaires, personal interview, field survey, observation and measurement (if any).

(b) The secondary source: This will include library search, internal review, the use of maps, town planning documents and other policy document etc.

\subsection{Method and Strategy for Data Collection}

To ensure objective data collection, the following procedures will be followed:

(a) Reconnaissance survey: To facilitate the collection of data a reconnaissance survey is to be carried out to identify relevant parameters.

(b) Identification of the various stages of change in function.

(c) Land use characteristics and analysis: An analysis of the land use (commercial) element will be done.

(d) A questionnaire will be designed to collect the required data.

Research assistants will help to disseminate the questionnaire which will cover a sample size of about 200 people irrespective of their sex, age, educational background, tribe or place of work. 


\subsubsection{Technique of Analysis}

Data from the above will be analyzed graphically and statistically as may be appropriate using bar graphs, pie charts and line graphs and percentage.

\subsubsection{Significance of the Study}

Over the years, the population of Anyigba has grown due to the fact that people have migrated to Anyigba to benefit from its functions (Administrative, Transportation, Commercial etc., the establishment of the university coupled with improved economy has drastically increased the rate of expansion and growth of Anyigba town. Again, it is noticed that Anyigba has some limitations and constraints; it is therefore thought necessary to study the commercial functions of the town. This study will help in solving some problems faced by dwellers while going about meeting their commercial needs.

Finally, the study will propose a good market (structure) and land sue map for Anyigba which will help avoid likely commercial problems in the nearest future.

\subsubsection{Limitations of the Study}

One major factor that could stand the way of this research work is inadequate literature in terms of library textbooks, necessary and vital information from the internet etc.

Another limitation to the success of this research work is short time available to the researcher.

\subsubsection{Hypothesis of the Study}

Hypothesis can be explained as an idea or explanation for something that is based on known facts but yet proved (Cambridge dictionary, 1995). The hypothesis of this research work is drawn below:

(1) Is Anyigba a fast growing town?

(2) Are the commercial facilities available in Anyigba adequate for its populace?

\subsubsection{Scope of the Study}

The scope of this study will cover Anyigba town especially the commercial aspect of the functions of the town.

\subsubsection{Review of Related Literature}

Commerce can be defined as all the activities connected with business; trade i.e. The act of buying and selling of goods or exchange of services (Cambridge Int'l dictionary, 1995). It has been truly said that (commercial activities) commerce begins "where civilization begins". Commercial activities started from the Bronze Age and the Iron age which were dependent on materials found only a few localities and usually carried over wide regions (Encyclopedia Britannica).

The history of commerce is closely connected with the development of the techniques of transportation and communication. Commerce, or the purchase and sale of goods and services are the consequence of the increasing development of the division of labour.

As commerce grow in size and complexity, this principle of the division of labour and exchange of products and services spread from family, tribal to local group units to districts, sectional, national, international and even worldwide trading areas. Commerce includes all trade of the world consisting of the exchange of the product of the nation of the world (Encyclopedias Britannica). Commerce is very important in any community or town in meeting the commercial needs of the dwellers or inhabitants. Such a town must have markets from which people can buy and sell commodity. Towns must be able to effectively perform their commercial functional by adequately meeting the needs of the people. This can be done by having numerous and affective markets within the town.

Commercial land use is the economic base of any area where major or if not all trading or commercial activities take place. It is a place where people gather in order to buy and sell things. It can be divided into: Central Business Districts (CBD), Shopping Centers, District Shopping Centers, Neighbourhood Shopping Centers, Local Stores or Market Place. Talking about the functions of towns, we see the towns as a point of specialized activity carry out tasks which are performed either at central, assessable place or where a high degree of population concentration is economically necessary (Harold Carter, 1981). The functions which a town perform is very essential. These functions most times, 
determine the rate of development of such areas, the rate of migration and the rate of land-use development.

Industrialization, or the growth of any special function, affects urbanization and vice versa, so that the size and spacing of cities is in part the product of the way in which the specialized task which cites perform- mining coal, making cars or providing rest and relaxation-are carried out. This means that consideration of these roles has to be married with that of general regional functions in any total explanation of the urban pattern (Harold, 1981). It is however apparent that the larger the city or the more advance the economy (in terms of western industrial capitalism) then the more multifunctional the city becomes. Berry (1972) in his latent dimension of the urban American system concluded that "as multifunctional towns lose distinction in economic specialization, it is the broader socio-economic dimension which emerges as bases of contrast. The distinctive towns specialized by their economic bases are small and unimportant. The one exception is the market oriented activities, for every urban system is hierarchically structured, the structure resting on aggregate economic power.

And as Berry (1981) also concludes, the functional size of centers in an urban hierarchy is a universally latent dimension. Two conclusions follow:

(1) Into the pattern of urban growth so far set out needs to be added a process of function change by which, as divergence of economic base are progressively dimensioned.

(2) The hierarchical structuring of towns depends mainly on the universal size dimension.

Functions of towns include the following:

(a) Education

(b) Commercial

(c) Center of industries and manufacturing

(d) Place of investment

(e) Locus of power

(f) Point of contact with the world etc.

From earliest times, chorographical works have description of town functions and have carried the implication that towns fall into classes or groups by virtue of the functions they perform. The simple designation "market town" or "seaport is a form of functional classification (Harold, 1981). The committee on the Health to Towns in Britain (8140) proposed five groups of classification of towns, which were:

(1) The metropolis

(2) Manufacturing towns

(3) Populous seaport towns

(4) Great watering places

(5) Country and other considerate inland towns not being the seats of particular manufactures.

Here Pierce (1915) classified cities into two groups based on their functions:

(1) Political intellectual centers e.g. Delhi, Lagos, Ibadan.

(2) Economic centers e.g. Onitsha, Aba, llesha.

Hoselitz (1955) classified cities into "generative" and parasitic' cities. The generative city has a favourable impact on the economic growth and the parasitic city the exact opposite. Redfield and Singer (1954) classified towns based on their cultural roles as "orthogenic" or 'heterorgenic'. The orthogenic city is "carrying forward into systematic and reflective dimension an old culture", cities of moral order and the heterorganic is "creating of original modes or thought that might have authority beyond or in with old cultural or civilization" cities of technical order. Hauser (1959) also classified cities as pre-industrial, industrial and metropolitan. Breeze (1966) found all these typologies to be inadequate to describe the situation in the developing counties and suggested"... it would be important to view urbanization in newly developing countries from several different perspectives and to classify where necessary for particular purposes in terms of size of urban area..." As noted above under the classification by Piene ( ). Anyigba is a political-intellectual and also an economic center since it houses a university, performs some administrative functions and also serves as an economic town.

In as much as mega-cities are increasing rapidly in number and population living in them, the rural area still account for the largest share of the population of the world, and the trend is expected to continues so in a foreseeable future. Besides, cities fewer than 500,000 people as place of residence account for the largest percentage of urban population. They are expected to still have dominance in the share of world population and is expected to live in small cities of 500,000 people.

Contrary to the situation in 1075 when the urban population in the developing countries/region concentrated in small cities, the tendency in the future (which started in 2000) is that the largest urban population has shifted to cities of in million people and by $2015,44.1 \%$ of the urban population of the developing region will belong to this category and more 
than half of the urban population in the developing regions will be in small cities.

\subsubsection{Anyigba: General Overview}

Anyigba has gradually emerged as the social and commercial headquarters of the Eastern Senatorial District of Kogi State which is the homeland of the Igalas (mainly) and the Bassas. The town has earned this status through a combination of vantage central Location within the Senatorial District and socio-economic activities in more recent years away from the cultural influence of Idah, the seat of traditional leadership of the Igalas (ATTAH of IGALA). The status of Anyigba town was further boosted in year 2000 with the establishment of a university i.e. (Kogi State University) within the town. This in turn has affected the type of land use in the area under study.

As at the year 2001, the major land use in Anyigba was mainly Residential (63.28\% of the total land area) inclusive of the residential quarters in the university (T.P.D.B., 2002). The population of Anyigba has increased to about 40.764 as at the year 2001 contrary to the estimated population figure of the Town by the Town Planning Development Board in their master plan for Anyigba from (1974-2005). As a result of the establishment of the university (mainly) and because people have migrated to Anyigba to benefit of its Commercial, Administrative, Economic functions etc.

The establishment of the university has encouraged migration of people to Anyigba Town. Many people have migrated from different parts of the State (Kogi) especially students; and from all over the country. Some of these people have come from as far as Kaduna, Maiduguri, Lagos, Gombe etc., to benefit from the educational functional of Anyigba.

This, coupled with the migration of people for some other purposes (residential, in cases of retirement etc) has led to a dramatic increase in the population of Anyigba Town.

It is worthy of note that as these people come to Anyigba from their different places and for different purposes, these is a need for their commercial needs to be met. These people need markets from within Anyigba where they could purchase their needs. Anyigba hitherto does not provide a satisfactory commercial function; people have to travel most times, long distances before they could purchase some items for themselves. This ought not to be so; people need markets from within Anyigba rather than travelling to far places for their commercial activities.

For example, one would have to travel to a place like Lokoja before you can get items like cartographic pens or even textbooks. Although Anyigba serves as a market (central place) in the region, it does not adequately satisfy the commercial needs of its inhabitants mainly because the kind of goods purchased by the nearby villages are somehow different from those purchased by inhabitants. Examples of such goods are palm oil, fruits etc for the region, for the inhabitants, goods like materials, books and goods for everyday use are needed. But for the inhabitants, it does not adequately and satisfactorily provide its commercial functions in terms of availability and quality.

\subsection{Functions of Anyigba as a Town}

The functions which Anyigba perform varies. Anyigba is a rapidly growing Agricultural town which is also an important commercial center in the region. Other functions of Anyigba include transportation, services, educational, residential, industrial etc.

\subsubsection{Industrial}

Anyigba town is not highly industrialized. The industries fall into the following categories: Agro-based, forests-based, metal-based, non-metal based and other manufacturing plants.

○ The Agro-based industries include: Baking, Garri processing and Rice Mill. Also, Shoe making/repairing, Tailoring and Textile (including weaving).

- The forest based include carpentry and joinery; saw milling, photography and printing/publishing lark works.

- The others are blacksmithing, Gold smithing, Watch repairing, Automobile, Mechanical and Electrical work, Hair dressing/Barbing, and Laundry.

\subsubsection{Services}

The term 'service' is used here to cover the activities including civil services, public service, financial institution, wholesale and retail trading and the informal private sector (transporters, auto-mechanic, masons, electrician etc). The proportion of the labour force involved in this group is increasing. This has brought a number of civil servants and these have generated attendant ripple effect in other areas. 


\subsection{Agriculture}

A large number of people are employed in the agricultural sector. This consists of crop agriculture, forestry, oil palm production, livestock farming (fisheries is not existent, but the migration of the Fulani herdemen has increased livestock activities).

\subsubsection{Markets And Trading}

There are a great number of people employed in the market system. There are about three markets in Anyigba of varying sizes; there are also some shopping places although there is no major shopping arcade in the city.

\subsubsection{Transportation}

Anyigba enjoys the privilege of being a nodal town with the emergence of many major roads in the town. It is a focus of intra and inter-regional road network. These Anyigba, Ankpa, Anyigba-Idah, Anyigba-Dekina and Anyigba -Abejukolo. Anyigba effectively (to an extent) performs this function to the region, thus, its central place role is enhanced by the road network.

\subsubsection{Educational}

Apart from the university, Anyigba has about five primary schools and also about five secondary schools. It provides educational functions effectively not only the Local Region but also to the State and the country (due to the university which attracts people from all over the country).

\subsubsection{Residential}

About $62.28 \%$ of the total land area of Anyigba is devoted to residential land use. This figure includes the residential quarters in the university. Anyigba conveniently provides a satisfactory residential function (in terms of land use).

\section{Historical Basis of the Commercial Nature of Anyigba Town}

Anyigba town from time has been an agricultural town. Its manufacturing sector was composed mainly of small-scale industries such as furniture making, rice milling, bakeries and crafts. The palm oil crushing mill on the north next to the stream, suspended production in 1974 due to marketing and harvesting difficulties (T.P.D.B.) carried out primarily in the traditional market held every four days.

According to Dar-al-Hadassah (1977) in his market survey of Anyigba town, about 5,800 buyers and sellers attend the market, approximately 55\% of whom are from surrounding villages like Egume, Olowa, Abocho, Ajiolo and Ankpa. $72 \%$ of the buyers walk to the market while others use bicycles (Anyigba master plan 1974-2005). Crops and foodstuffs mainly Maize, Guinea corn, Yam, Cassava, Beans, Soup ingredient, Meat and Fish constitute over 80\% of the goods traded (Dar-al-Hadassah, 1977).

\section{Commercial Functions in Analysis}

Anyigba as a town performs some commercial functions although inadequate. Anyigba has about three markets of varying sizes and also some shopping center/places around the town although there is no major shopping area in the town. Over the years (especially before year, 2000), the level of demand for commercial activities was very low compared to what is obtained now. This is attributed mostly to the fact that most of the dwellers are farmers and they produce their food subsistently and so they hardly purchase goods outside those available at the local market.

Many people have migrated to Anyigba town to benefit from its various functions especially students for educational functions of the town. There is therefore the need for their commercial needs to be met. They need a market where they could purchase their needs.

Anyigba as a town has not been performing this function effectively especially to migrants; most of which are students of Kogi State University. This could mainly be as a result of the choice or rather attitude of migrants in purchase of goods. These migrants especially the students are from cities and they have high taste in purchasing goods. This 
therefore makes the goods in Anyigba of low quality (if available). Also, most of the goods sold in the market are still patterned to satisfy the needs of the 'former' or rather initial dwellers at the expense of new migrants.

As a matter of fact, the commercial land use data for Anyigba by the United Nations Development Programme, 2001, account for about $0.211 \mathrm{~km}$ of the total urban metropolitan area as compared to about $0.165 \mathrm{~km}^{2}$ as contained in the master plan for Anyigba from 1974-2005 (T.P.D.A.). This shows slight increase in commercial activities resulting in low commercial land use. Even in the existing markets in Anyigba, there is lack of organization in the manner of arrangement of goods for sale. This is yet another problem in adequately performing its commercial functions. For goods available, we find out that the quality of such goods is low, Clothes for example.

\section{Research Methodology}

This chapter describes the population and method of sample completion, data collection techniques and method of data analysis adopted in carrying out this research work.

\section{Populations and Method of Sample Collection}

Population is the number of people (or animals) living in an area. For the purpose of this research work, the population covers Anyigba town, male and female irrespective of their age, work, educational background etc.

\section{Data Collection}

There are two main ways of collecting data. These are the primary and secondary methods. In the primary method, the researcher specifically sources his information using questionnaires and observations, while in the secondary source; data is gotten from past documentations and from literatures by other writers. Data used in this study were mainly primary collection from the said population of 200 people and secondary source was not left out.

The advantages of using primary method included:

(a) It enables the researcher to obtain the exact information needed because it is original and the researcher is the only one who studies it.

(b) There is closer control and supervision of data collected so that necessary adjustments are made immediately.

(c) The limitation to the use of data is known. This is because it is safety collected, the limitation to the use of this data and time is known.

The merits of using secondary method are

(a) It saves time, because it is obtained from existing sources unlike primary data.

(b) It is easy to obtain and it is less expensive

(c) There is availability of varieties on a wider range including other subjects.

\section{Interview Method}

This is designed to enable the researcher have the knowledge of the commercial functions of Anyigba. Meanwhile interview is a face-to-face discussion between the interviewers and the respondent; it is applicable when dealing with population.

This method was necessitated due to the following reasons:

(i) Situations arose where further comments were necessary on the subject of study outside the scope of the questionnaire.

(ii) It aided clarity of some questions in the questionnaire, thus creating an interaction between respondents and the researchers.

(iii) Some information were obtained where the questionnaire proved abortive.

\subsection{Sample Method}

This is a part of the population that is taken to give ideas of the quality of the entire population under this method, this probability method are available. Probability samplings are collected according to laws of chance; that is Random samples. 


\subsection{Merits of Using Sampling Method}

(1) It saves time and chances of errors are minimized.

(2) It has greater scope of cover and quick result is obtained.

(3) With sample method, it is possible to carry out several surveys of studies concurrently while worry resources efficiently.

(4) Errors can be assessed and corrected.

Basically, in collecting data for the completion of this project, the sample size chosen is 200 (Two hundred). The interview and questionnaire methods formed part of source of data (primary) needed. The secondary data was collected from related textbooks and journals.

All is to test the hypothesis that the commercial function of Anyigba is inadequate in meeting the needs of the dwellers/inhabitations.

\subsection{Analysis of Data}

The basis of this project is to study the adequacy of the commercial function of Anyigba town. Therefore in analysis the result obtained, the following steps were taken.

(1) Read through the questionnaires and studies carefully the responses.

(2) Selection of the correctly answered questions and otherwise.

(3) Work on those correctly answered.

(4) Take decision in relation to the hypothesis while making references to the positive negative responses obtained.

\subsection{Analysis of the Questionnaires Received}

In total, 200 questionnaires were given out. Out or these, 190 were returned while 10 were not properly answered leaving the balance of 180 to make use of.

(1) The questionnaires were filled by 70 males and 110 females.

(2) It was mostly filled by the age classification of between 21-40 (120 people), 5 people between 0-20 years, 40 people between $41-60$ years and 15 people between 61 and above.

(3) All the respondents are Nigerians.

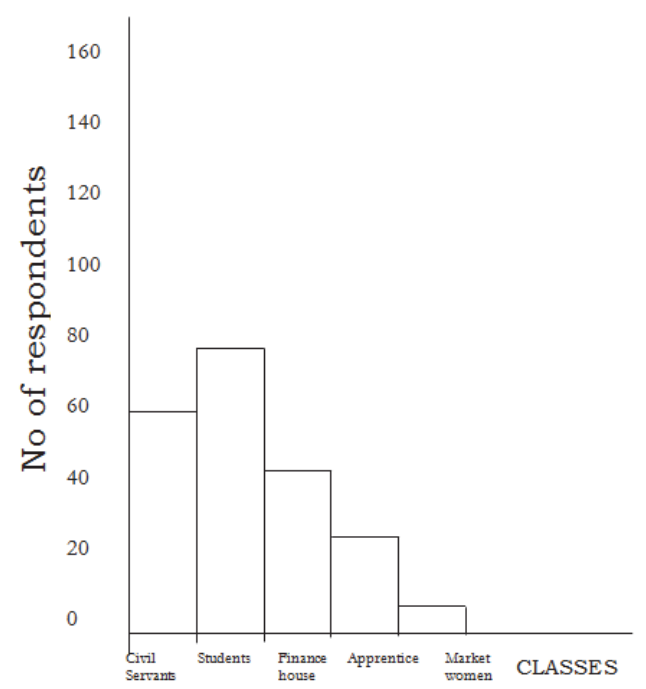

Q4. Age bar chart showing the age range of respondents let $1.5 \mathrm{~cm}$ rep. age range on $\mathrm{X}$-axis. 
Let $1.5 \mathrm{~cm}$ rep. 20 respondents on $\mathrm{Y}$-axis. From the chart it can be seen that the respondents are proportionally ranged all the age range needs markets from where their commercial needs can be met and therefore in one way or another use the markets within Anyigba Town. Q5. Going through the analysis, all classes listed were finally analysed.

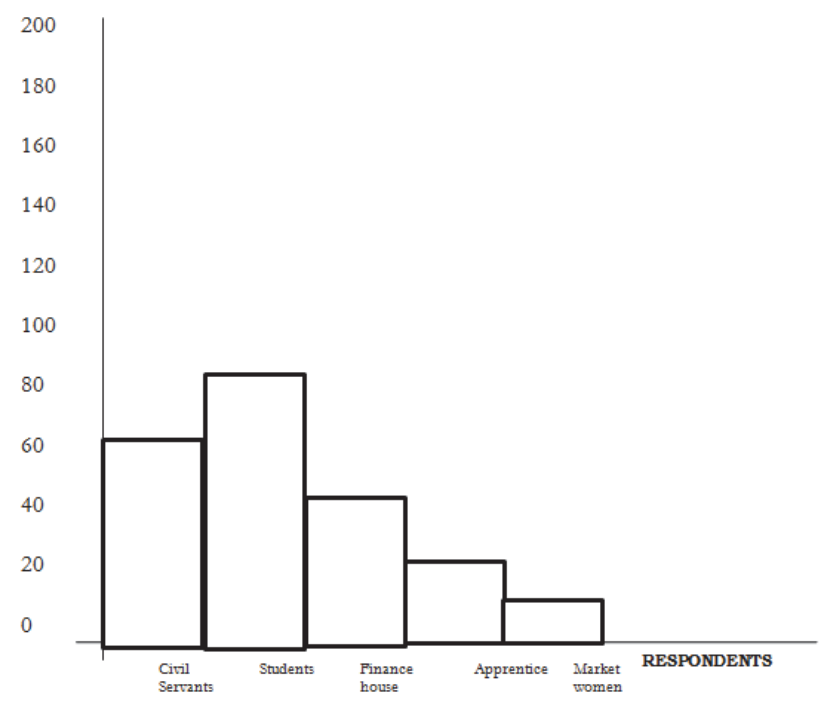

In analyzing the respondents above the different classes are easily traced.

1. Finance Houses

$$
30 / 180 \times 360 / 1=60^{\circ}
$$

2. Apprentice

$$
20 / 180 \times 360 / 1=40^{\circ}
$$

3. Civil servants

$$
50 / 180 \times 360 / 1=100^{\circ}
$$

4. Students

$$
70 / 180 \times 360 / 1=140^{\circ}
$$

\section{Market women}

$$
10 / 180 \times 360 / 1=20^{\circ}
$$

These are the result obtained from the questionnaires administered. Moreover effort were made to get more facts or views of some respondents who could not collect the questionnaire due to unprecedented limitations. The interview questions were not different from those in the questionnaire; neither were the responses received in total difference either. 


\section{Summary, Conclusion and Recommendations}

\subsection{Summary}

This study was carried out to ascertain the adequacy of the commercial functions of Anyigba town. After the collection of the questionnaires, the responses were carefully analyzed using the given information. It was discovered from the responses that people are not satisfied with the commercial functions of Anyigba in that it does it adequately meet their commercial needs satisfactorily.

\section{Conclusion}

Based on the major findings of this study, it can be concluded that the commercial function of Anyigba is inadequate and that in the existing market there is lack of organization in the manner of arrangement of goods which make it difficult for people to easily locate stalls were they could buy their goods.

\section{Recommendations}

The researcher puts forward the following recommendation

(1) The market men and women should be encouraged to take loans especially cooperative loans so as to purchase more quality goods for sale.

(2) That the concerned Authority on the maintenance of the market should disallow any illegal stalls and or arrangements.

(3) That the local government Authority should ensure adequate cleaning of dirts from the market (to avoid contamination of foodstuffs).

(4) A new plan for rearrangement of the stalls should be made where homogenous goods are placed together. This will enhance the beauty of the existing market and easy access to goods needed.

(5) Cornser shops should be constructed within the Central Business District of the town and shopping complexes within certain streets.

(6) An update of the master plan (1974-2005) should be done in the markets. This will give room for large variety of goods to be sold.

\section{References}

Breeze, O. (1966) Urbanization in Newly Developing Countries, Prentice Hall, London.

Carter, H. (1981) The Study of Urban Geography, Edward Arnold, London.

Cambridge International Dictionary, (1995).

Dar-al-Handassah (1977) Anyigba Master Plan 1974-2005.

Encyclopedia Britannica

United Nations Development Urban and Housing Indication Programme 2002 Study: Kogi State Segment. 